\title{
A new Paleo-Tethyan HP-UHP metamorphic belt identified in the southeastern Tibetan Plateau
}

\author{
HUINING WANG ${ }^{1}$, FULAI LIU ${ }^{1}$ AND ZAIBO SUN ${ }^{2}$
}

${ }^{1}$ Institute of Geology, Chinese Academy of Geological Sciences

${ }^{2}$ Yunnan Institute of Geological Survey, Kunming, China

Presenting Author: wanghuining1@126.com

The Changning-Menglian orogenic belts (CMOB) in the southeastern Tibetan Plateau has been regarded as remnants of main Paleo-Tethys that formed by the separation of Sibumasuand Eurasia-derived blocks. Here, we report the first discovery of blueschists and eclogites that occur as lenses or blocks hosted by mica schists, and these rocks form an elongate and north-southtrending high-pressure (HP)-ultrahigh-pressure (UHP) metamorphic belt that is $\sim 200 \mathrm{~km}$ long and $\sim 50 \mathrm{~km}$ wide. The newly discovered epidote-magnesioriebeckite schists, garnetferroglaucophane schists, phengite/talc-glaucophane eclogites, lawsonite-talc-phengite eclogites and dolomite/magnesitekyanite eclogites have MORB- and OIB-like affinities and positive $\varepsilon_{\mathrm{Nd}}$ values, which suggests an enriched and depleted oceanic lithosphere source for protoliths. Magmatic zircons from eclogites and blueschists yielded protolith ages of 451-250 Ma, which fit well within the time frame for the spreading of PaleoTethys. Combined with previous isotopic data, we establish periods of Early-Middle Triassic (246-227 Ma) and Late Triassic (222-209 Ma) as ages of subduction and exhumation, respectively. Blueschists and eclogites record distinct peak metamorphic conditions from lawsonite blueschist facies, through lawsonite eclogite facies, until kyanite eclogite facies, suggesting mantle depths of $\sim 50-95 \mathrm{~km}$. These rocks record clockwise $P-T-t$ paths characterized by a prograde loop under a low geothermal gradient $\left(5-10{ }^{\circ} \mathrm{C} / \mathrm{km}\right)$, indicating rapid-cold subduction at a rate of $4.5-6.0 \mathrm{~km} / \mathrm{Ma}$, followed by isothermal or cooling-decompression and exhumation at an average rate of $3.2-4.2 \mathrm{~km} / \mathrm{Ma}$. Similarities of petrology, geochemistry, and geochronology for eclogites and blueschists of CMOB and ones of Longmu Co-Shuanghu suture provide powerful support for the idea that a nearly $2000 \mathrm{~km}$ long HP-UHP metamorphic belt extends from northern to southeastern Tibetan Plateau, and that it represents the main boundary suture of Paleo-Tethyan domain. These results have far-reaching implications for tectonic framework and metamorphic evolution of Paleo-Tethys. 